
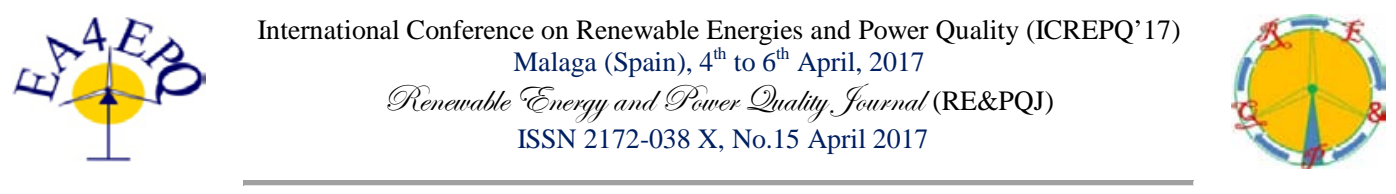

\title{
PV Solar System for Stand Alone Smart Home with DC Supply
}

\author{
M. Nassereddine ${ }^{1}$, J. Rizk ${ }^{2}$ M. Nagrial ${ }^{2}$ and A. Hellany ${ }^{2}$ \\ ${ }^{1}$ Senior Engineer, National Electrical Engineering Consultancy, Sydney, Australia \\ ${ }^{2}$ School of Computing, Engineering \& Mathematics \\ Western Sydney University \\ Penrith, Australia \\ e-mail: m.nagrial@westersydney.edu.au
}

\begin{abstract}
Renewable energy is becoming an essential element when it comes to climate change. The advance technology in energy storage increases the installation of stand alone system for residential houses. The paper addresses the stand alone PV solar system for sustainable house. It includes information regarding the household equipment operating voltages and the advantages of the DC system. A case study is included to outline DC protection for voltage sensing.
\end{abstract}

\section{Key words}

Renewable Energy, Solar System, Stand alone house.

\section{Introduction}

Climate change is a contemporary issue, and the international community have accepted the dangers of greenhouse gas emissions. Methodologies and policies to address this important issue, is now a popularly debated topic. Renewable energy is one of the hot topics to reduce greenhouse gas emissions. Solar system is one of the renewable energy power sources that can help in reducing the carbon dioxide.

Solar electrical system has been implemented in two forms [1-5]:

- $\quad$ Grid connected systems.

- $\quad$ Stand alone system.

The existing knowledge for both stand alone and grid connected system, utilises for most cases the DC-AC inverter to power the household equipment [1-8]. The existing stand alone system utilises an inverter to power the household using the energy from the PV solar system and the installed batteries. The system usually includes the following:

- Charger controller

- DC-AC inverter

The inverter introduces additional losses to the system with maximum efficiency at the rated power. The system will be operated at rated power only for short period during the day. The system will be operated at less than $50 \%$ of the inverter rated power at other times. Therefore, the removal of the inverter will enhance the system efficiency. This paper addresses the DC installation for standalone solar system. The paper focuses on the advance use of the DC system, its wiring and protection requirements. A case study is also included.

\section{Theoretical Study}

This section is divided into the following subsections:

- Advantages of DC standalone PV solar house

- DC wiring requirements

- Protection of the DC house

\section{A. System advantages}

Figure 1 shows the arrangement of the DC house. Table 1 shows the typical household equipment. It shows that most of the essential equipment can operate using DC power. Furthermore, the table shows that the most frequent used items (light, TV, charger and stereo) contain an internal AC/DC inverter when operating using AC power source. The house wiring using DC system will increase the efficiency of these items by eliminating the AC/DC inverter requirements.

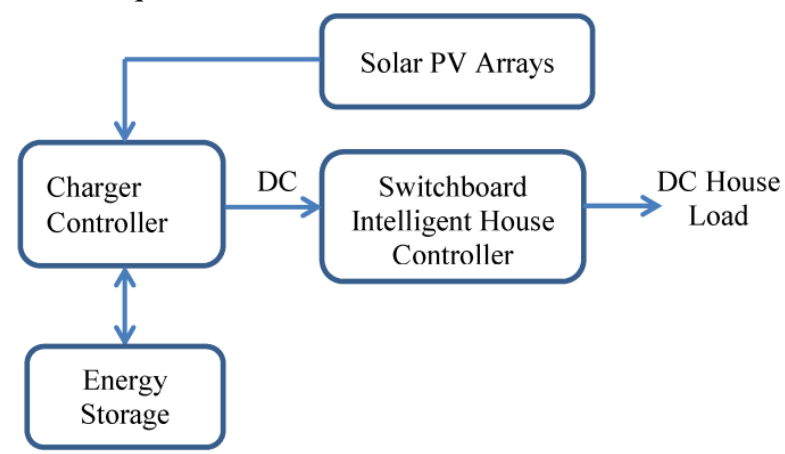

Fig 1: Stand alone DC house circuit layout 
Table I: Household equipment

\begin{tabular}{|c|c|c|}
\hline $\begin{array}{l}\text { Equipment } \\
\text { Description }\end{array}$ & $\begin{array}{l}\text { Operating } \\
\text { Voltage }\end{array}$ & Comments \\
\hline $\begin{array}{l}\text { Light-LED down } \\
\text { light will be used } \\
\text { for the house }\end{array}$ & $\begin{array}{l}\text { DC } \\
\text { voltage }\end{array}$ & $\begin{array}{l}\text { The common LED down light } \\
\text { installation utilises a } \\
\text { standalone AC/DC inverter to } \\
\text { power the globe }\end{array}$ \\
\hline $\begin{array}{l}\text { TV-LED TV will } \\
\text { be used }\end{array}$ & $\begin{array}{l}\text { DC } \\
\text { voltage }\end{array}$ & $\begin{array}{l}\text { The TV system contains an } \\
\text { internal AC/DC inverter. }\end{array}$ \\
\hline Sound Systems & $\begin{array}{l}\text { DC } \\
\text { voltage }\end{array}$ & $\begin{array}{l}\text { The stereo system contains an } \\
\text { internal AC/DC inverter }\end{array}$ \\
\hline Charger & $\begin{array}{l}\text { DC } \\
\text { voltage }\end{array}$ & $\begin{array}{l}\text { Charger contains an internal } \\
\text { AC/DC inverter }\end{array}$ \\
\hline Fridges & $\begin{array}{l}\text { DC or AC } \\
\text { input } \\
\text { power }\end{array}$ & \\
\hline $\begin{array}{l}\text { Washing } \\
\text { Machine }\end{array}$ & $\begin{array}{l}\text { DC or AC } \\
\text { input } \\
\text { power }\end{array}$ & \\
\hline Oven Stove & $\begin{array}{l}\text { DC or AC } \\
\text { input } \\
\text { power }\end{array}$ & $\begin{array}{l}\text { Gas will be used to power the } \\
\text { stove and oven }\end{array}$ \\
\hline Hot Water & & $\begin{array}{l}\text { Solar hot water system will be } \\
\text { used }\end{array}$ \\
\hline Small appliances & $\begin{array}{l}\text { DC or AC } \\
\text { input } \\
\text { power }\end{array}$ & \\
\hline Air-Conditioner & $\begin{array}{l}\text { DC or AC } \\
\text { input } \\
\text { power }\end{array}$ & \\
\hline $\begin{array}{l}\text { Kitchen AC } \\
\text { appliances }\end{array}$ & $230 \mathrm{~V}$ & $\begin{array}{l}\text { A special } 1000 \mathrm{~W} \text { inverter will } \\
\text { be located within the kitchen } \\
\text { walls to power these special } \\
\text { equipment }\end{array}$ \\
\hline
\end{tabular}

The DC house ensures the equipment is always operating at maximum efficiency as it provides the required power voltage at its terminal.

Figure 1 can be revised to include the grid connection as shown in figure 2. It ensures the inverter is always operated at its highest efficiency.

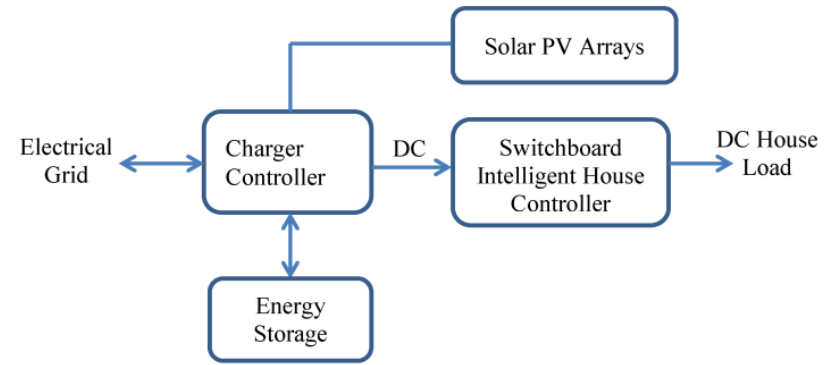

Fig. 2: Stand alone DC house with Grid connected charger

The following example shows the saving between DC and AC powered lighting. Different types of transformers are used for the assessment. It should be noted that the outputs in figure 3 is based on 3 different types of transformer for LED. Each transformer has different level of power consumption (type A transformer consumes 2.6W, transformer, type $\mathrm{B}$ consumes $1.6 \mathrm{~W}$ and transformer $\mathrm{C}$ consumes 3.1W)

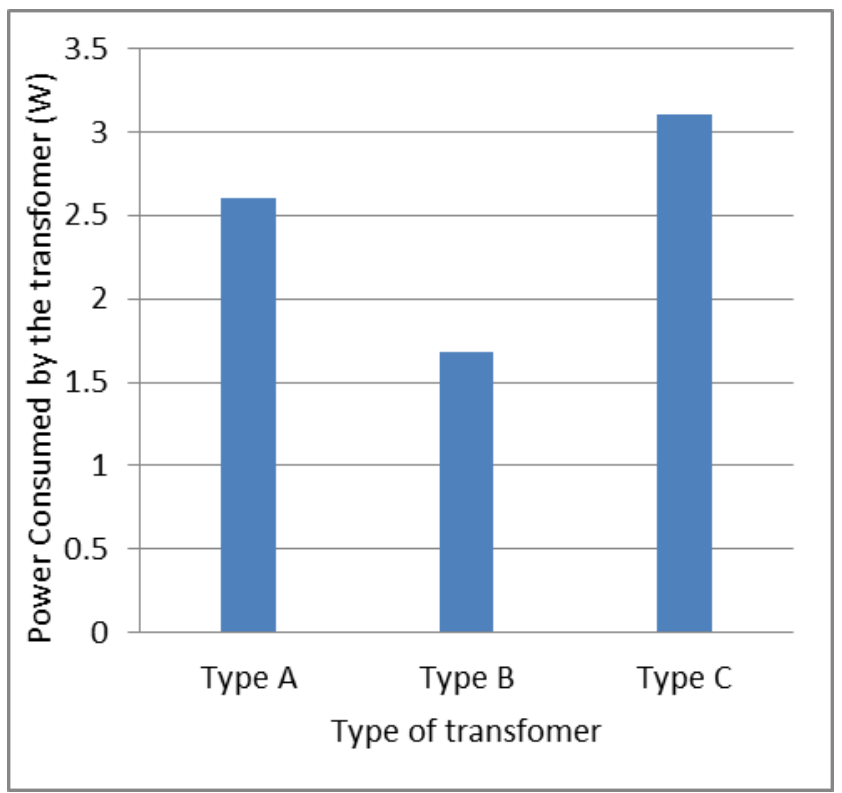

Fig. 3: Power consumption for the transformer when powering 12W LED light

Figure 4 shows the AC and DC power consumption to run the entire light for an hour for a house with $30 \mathrm{x} 12 \mathrm{~W}$ LED down lights. Figure 5 shows the saving when converting from AC to DC circuit. The figure shows that if the light is operating 10 hours per day, the saving will be between $500 \mathrm{Wh}$ to almost $1 \mathrm{kWh}$ per day. This saving is significant when it comes to energy usage and storage. According to [9], the cost is around AU\$1000 (US\$750) per kWh battery storage, therefore, the DC wiring has a saving between $\$ 500$ and $\$ 1000$ just for the LED system.

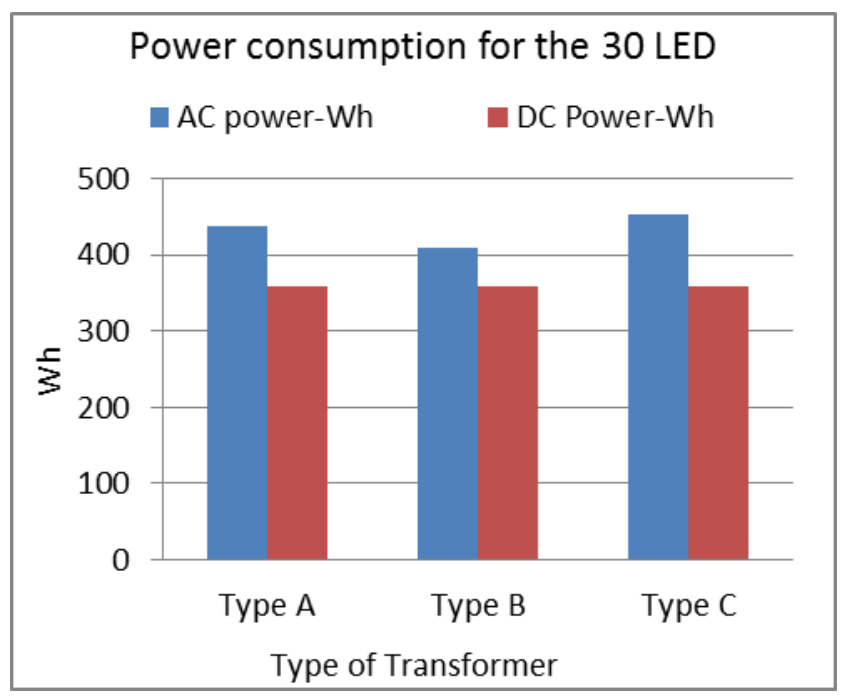

Fig. 4: AC and DC power consumption to run the entire LED lighting 


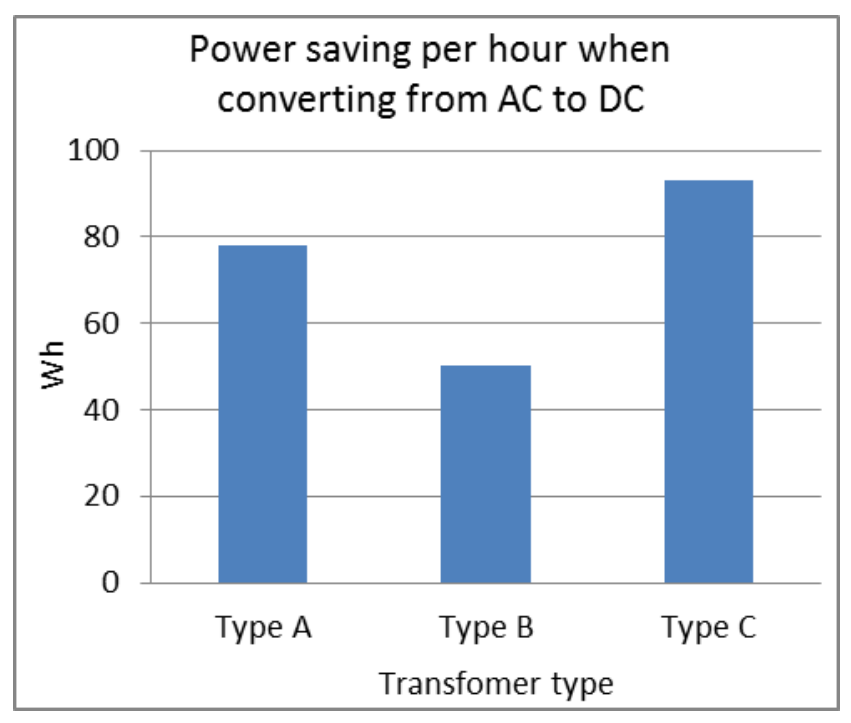

Fig. 5: Power saving when converting from AC to DC for the LED lighting

The above example shows the significant saving on power consumptions, battery storage and cost of the system. Taking into consideration the additional power saving when it comes to TV, radio, stereo and chargers, the DC houses reduce the cost and enhance the efficiency of the system.

Figure 6 shows the smart house logic that controls the electrical system. The logic works toward enhancing the battery life by reducing the number or charging cycle. It can be achieved by feeding the load direct from the PV solar power where applicable. It manages any surplus PV power in an efficient way. For example, in summer, the solar system might generate surplus power during the day. During this scenario, the smart house controller directs this power to the nominated loads such as air-conditioner.

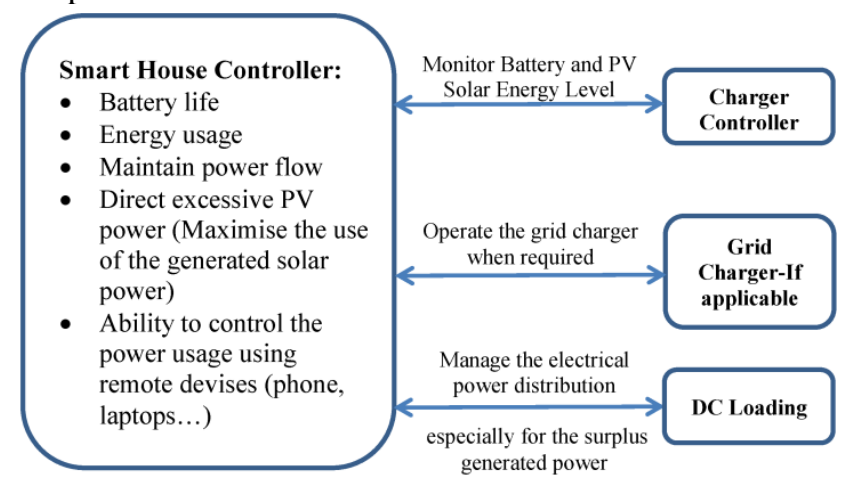

Fig. 6: Smart house controller

\section{B. DC Wiring}

The main different between the AC and DC wiring is the current rating and insulation of the cable. As household is operating at low voltage, this paper considers only the current rating of the cable.

The following example uses the $30 \times 12 \mathrm{~W}$ LED light. Table 2 shows the current required to operate the LED system under different voltages.
Table II: Cable current rating for different voltage

\begin{tabular}{|c|c|c|c|}
\hline Voltage & Type & $\begin{array}{c}\text { Power } \\
(\mathrm{W})\end{array}$ & $\begin{array}{c}\text { Current } \\
(\mathrm{A})\end{array}$ \\
\hline 230 & AC & $410-453$ & $1.78-1.97$ \\
\hline 12 & DC & 360 & 30 \\
\hline 24 & DC & 360 & 15 \\
\hline 36 & DC & 360 & 10 \\
\hline 48 & DC & 360 & 7.5 \\
\hline
\end{tabular}

Based on table 2, the LED light should be split into two circuits if $1.5 \mathrm{~mm}^{2}$ cable is used to power the system at $12 \mathrm{v}$. The following items should use large cross section cable:

- Refrigeration

- Washing machine

- Air-Conditioner

For example, for $1 \mathrm{~kW}$ refrigeration, $25 \mathrm{~mm}^{2}$ is required for $12 \mathrm{~V}$ and $10 \mathrm{~mm}^{2}$ is required for $24 \mathrm{~V}$ system.

The Air-Condition system requires large cable if operating at 12 or 24 volts system. At this voltage level, a standalone inverter could be more cost effective than the DC wiring. Separate assessment shall be completed based on the size of the unit.

\section{DC Protection}

The circuit protection ensures system safety and adequate operation of the installed wiring. The extra low voltage system, in many countries, has no safety risks on the house occupants. The protection is still required to protect the system. Wide range of DC circuit breakers and fuses are available in the current market $[10,11]$. However, all the available devices protect the system from over current. No devices are available that protect from leakage current or voltage. For example, if the negative terminal of the DC system gets in contact with earth, the current is below the tripping requirements. Therefore, the circuit breaker will not operate and the system won't detect the fault. The mentioned fault impacts on the life of the battery and the integrity of the system.

Tis paper introduces the voltage sensing between earth and both terminals of the battery system. The proposed concept allows the system to detect any voltage changes between the earth and +/- terminals. Figure 7 shows the proposed circuit, with the following operation concepts:

For a fault between the $(+)$ or $(-)$ terminals and the earth, the $S_{E}$ will sense the voltage, even the current is neglected for the DC breaker requirements, and force the breaker to operate. For a $(+)$ fault to earth, the $S_{E}$ internal circuit allows for the (-) terminal and earth to form a complete circuit which will force the circuit breaker to operate. A similar phenomenon is followed for a fault at the (-) terminal. 


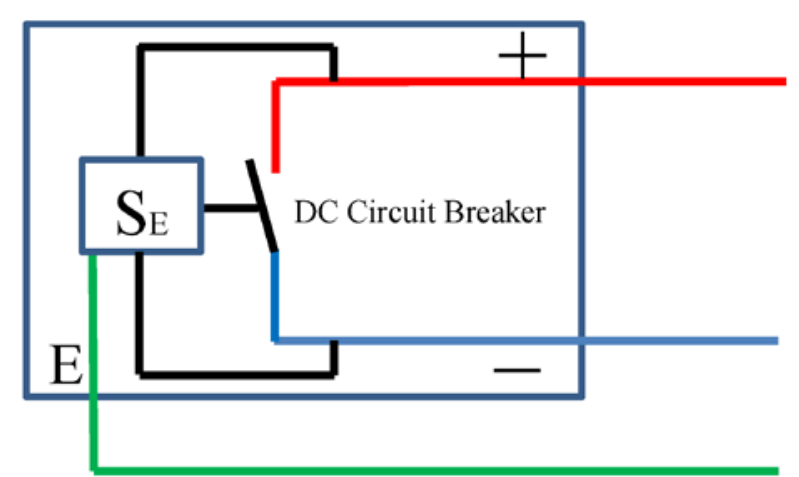

Fig. 7: Proposed DC circuit breaker to operate on voltage sensing

\section{Case Study}

A new house is under construction within the Western Sydney area. The electrical system will power the following household equipment's:

- Refrigeration

- Air-conditioner

- Lights

- Television

- Computer and phone chargers

- Washing cleaner

- Kettle

- Vacuum Machine

- Microwave

$10 \mathrm{~kW}$ solar panels will be installed on the roof of the new house. The following subsections assess the followings:

- Electrical load assessment

- Wiring requirements

- Protections circuit

\section{A. Load Assessment}

Household has the electrical requirements as per table 3 . A24V 5kWh battery is to be used to support the load of the house.

Table III: Household electrical loading

\begin{tabular}{|l|c|c|}
\hline & \multicolumn{2}{|c|}{ DC Loading } \\
\hline $\begin{array}{l}\text { Product } \\
\text { Description }\end{array}$ & $\begin{array}{c}\text { Electrical Load } \\
(\mathrm{W})\end{array}$ & $\begin{array}{c}\text { Electrical Load } \\
\text { Wh/day }\end{array}$ \\
\hline $\begin{array}{l}\text { 290L } \\
\text { refrigeration }\end{array}$ & & 900 \\
\hline $\begin{array}{l}\text { Washing } \\
\text { Machine }\end{array}$ & & 500 \\
\hline 1L Kettle & 200 & 200 \\
\hline TV & 50 & 500 \\
\hline LED light & 12 & $2880^{*}$ \\
\hline Air-conditioner & 1200 & $4800^{* *}$ \\
\hline Chargers & 100 & 200 \\
\hline Microwave & 1000 & 500 \\
\hline & Total $\mathrm{kWh} /$ day & $5.68^{* * *}$ \\
& & $10.480^{* * * *}$ \\
\hline
\end{tabular}

*30 LED down-light is installed at the house and assumed that all lights will be on 8 hours/day

**air-condition is running 4 hours/day at full load during summer period

$* * * \mathrm{kWh}$ required per day during winter

$* * * * \mathrm{kWh}$ required per day during summer

\section{B. Load Discussions}

Figure 8 represents the mean daily sunshine hours for Sydney [12]. It shows the lowest sun hour is for June. The $10 \mathrm{~kW}$ systems is capable of generating between 40 and $75 \mathrm{kWh}$ per day depending on the month. It is clearly shown that surplus power is generated by the installed system. The paper proposes two options to maximize the use of this power,

1. Option\#1: Install $75 \mathrm{kWh}$ battery systems and run more appliances using the stored energy

2. Option\#2: Use the smart house controller to make use of the surplus power while maintaining the $15 \mathrm{kWh}$ storage.

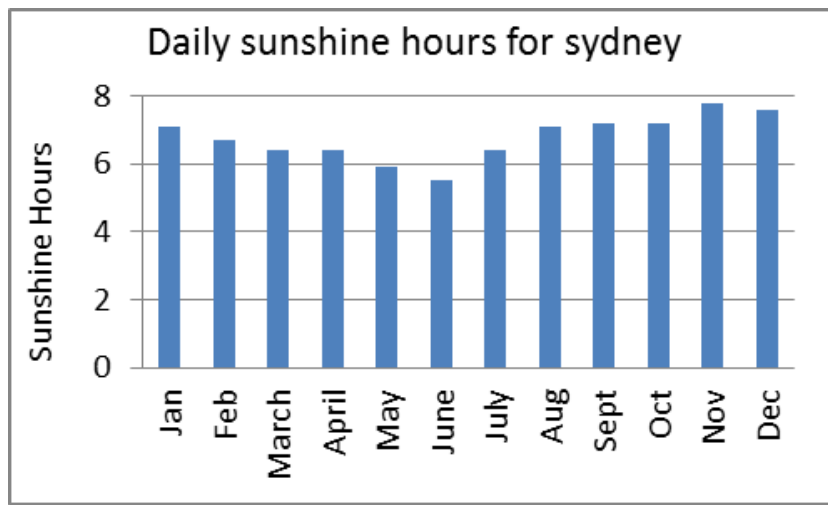

Fig. 8: Sydney daily sunshine hours [12]

Option\#2 is rather attractive due to the cost of the battery storage. The following two scenarios are used for the proposed house.

The generated solar system exceeds the storage system. The smart house controller dissipates the generated power as per figure 9. The controller allows the house owner to choose between different activities. For example, if there is a washing load, the controller can be set to operate the washing machine as first priority.

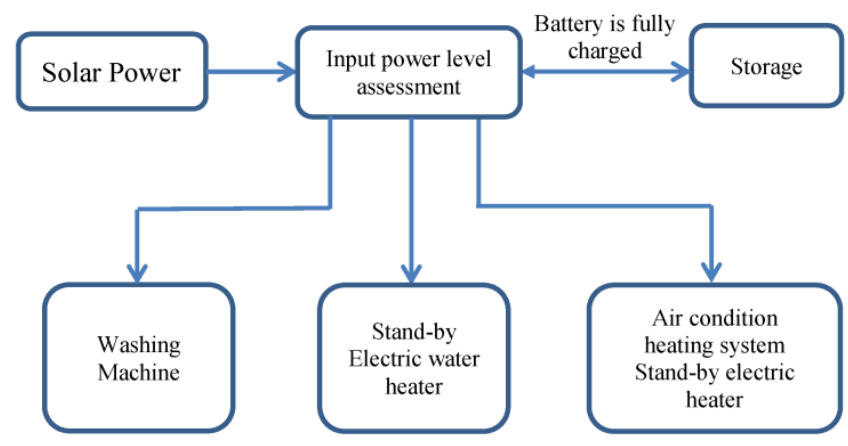

Fig. 9: Smart house flow diagram

\section{DC Wiring}

The DC wiring should take into consideration the current requirements for each electrical component. Table 4 shows the basic cable requirements for each household. Figure 10 shows the layout of the electrical circuit for the proposed house. It shows the number of circuit breakers and sub-circuits required to monitor the operation of the house. The installation should take into consideration the 
wiring requirements, for example, the stand-by electric hot water system will be installed near the solar system to save on wiring cost and drop voltage.

Table IV: DC wiring size requirements

\begin{tabular}{|l|c|c|}
\hline & \multicolumn{2}{|c|}{ DC Loading } \\
\hline Product Description & $\begin{array}{c}\text { Electrical Load } \\
\text { (W) }\end{array}$ & $\begin{array}{c}\text { Cable } \\
\mathrm{mm}^{2}\end{array}$ \\
\hline 290L Refrigeration & 1200 (Start-up) & 6 \\
\hline Washing Machine & 500 & 2.5 \\
\hline 1L Kettle & 200 & 2.5 \\
\hline TV & 50 & 1.5 \\
\hline LED light & 360 & 1.5 \\
\hline Air-conditioner & 1200 & 6 \\
\hline
\end{tabular}

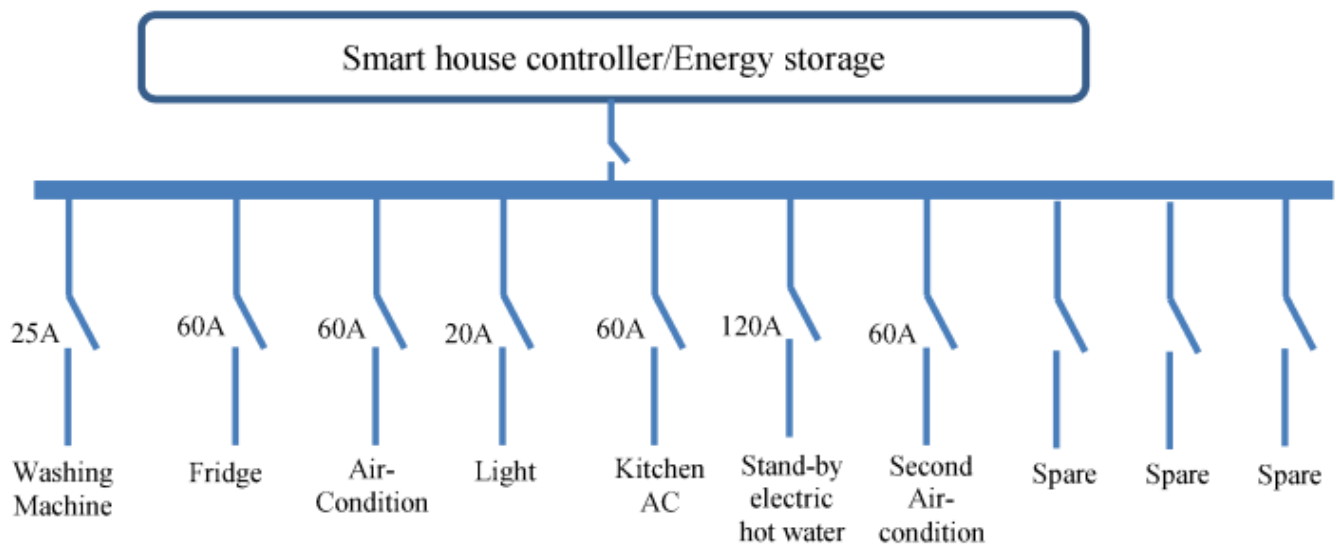

Fig. 10: DC board circuit

\section{DC protection}

As discussed in section 2.3, the current DC protection knowledge relies on overcurrent circuit breaker (the fault current magnitude must exceed the tripping requirement of the installed circuit breaker). If the (-) terminal touched the body of the washing machine, the current generated might not exceed the 25A and the circuit breaker will not operate. To ensure this issue is addressed, the paper modifies the circuit breaker to include the circuit in figure 11. The circuit shows, when the (-) get in contact with earth, the current flow between $(+)$ and earth and allow for the transistor to open and trigger the tripping of the circuit breaker. Similar circuit arrangement is also used for a $(+)$ fault to ground.

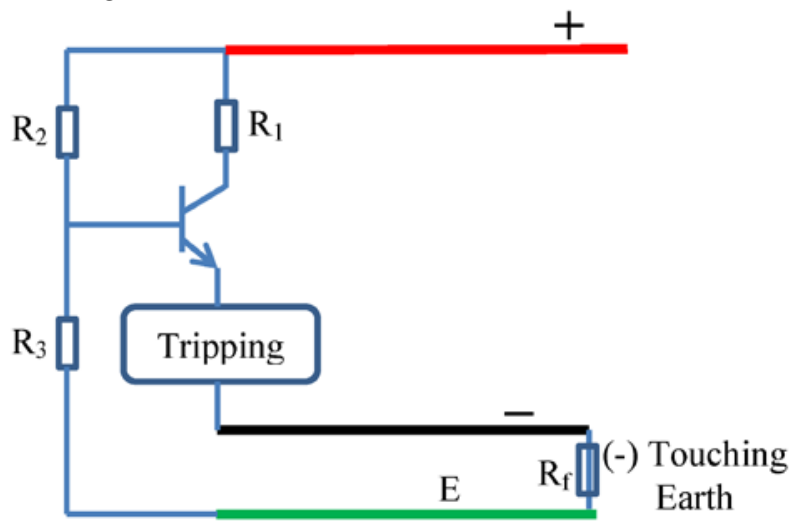

Fig. 11: Proposed tripping circuit for voltage leakage

It should be noted that the above circuit breaker arrangement requires separate earthing for earth feed. It

\begin{tabular}{|l|c|c|}
\hline Chargers & 100 & 1.5 \\
\hline Microwave & 1000 & 6 \\
\hline
\end{tabular}

means that each circuit breaker will have its own standalone earthing circuit.

\section{Conclusion}

The paper addresses the minimum requirements for a stand alone DC solar system for a residential house. It shows the system basic elements along with the controller basic functions. The DC house enhances the efficiency of the entire system by reducing the electrical losses. The works also show the wiring requirements for the proposed house. It shows the different types of wiring required for different household equipment. Furthermore, the paper introduces the concept of voltage sensing for DC circuit breakers. This contribution enhances the performance of the DC circuit breaker and gives it more control over the installed system.

\section{References}

[1] Lakshmo M., Sai Babu C. and Prasad S. "Design of off-grid homes with renewable energy sources" IET Chennai 3rd International Conference on Sustainable Energy and Intelligent Systems. 27-29 Dec. Tiruchengode, 2012

[2] Menka D., Shailendra S. and Rakesh S. "Solar PV standalone water pumping system employing PMSM drive” IEEE Conference on Electrical, Electronics and Computer Science. 12 March. Bhopal 2014.

[3] Das M. and Agarwal V. "Novel high performance standalone solar PV system with high gain, high efficiency DCDC converter power stages” IEEE Transactions on Industry Applications. Issue 99. Vol. PP.

[4] Swarna K., Oo V., Shafiullah M. and Stojcevski A. "Modelling and power quality analysis of a grid connected solar PV system" Australasian Universities Power Engineering Conference. 28 Sept. Perth 2014 
[5] Jain. S and Agarwal V. "A single stage grid connected inverter topology for solar PV systems with maximum power point tracking” IEEE Transactions on Power Electronics. Vol. 22. Issue 5. PP. 1928-1940. 2007

[6] Roman E., Alonso R., Ibanez P., Elorduizapatarietxe S. and Guitia D. "Intelligent PV module for grid connected PV systems" IEEE Transaction on Industrial Electronics. Vol. 53. Issue 4. PP. 1066-1073. 2006

[7] Teymour R., Sutanto D., Muttaqi M. and Ciufo P. "Solar PV and battery storage integration using a new configuration of three level NPC inverter with advanced control strategy" IEEE Transaction on Energy Conversion. Vol. 29. Issue 2. PP. 354365. 2014.

[8] February J., Mbav N. and Chowdhury S. "Economic analysis of standalone residential solar PV system for a typical south African middle income household" 48th international University Power Engineering conference. 2-5 Sept. Dublin. 2013.

[9] Parkinson G. "LG Chem pushes Australian battery storage prices further down the curve" published on the reneweconomy on 23 July 2015. Accessed 25-08-2015.

http://reneweconomy.com.au/2015/lg-chem-pushes-australianbattery-storage-prices-further-down-the-curve-40369

[10] Bingjian Y., Gyan G., Ziaoguang and Zhiyuan H. "A hybrid circuit breaker for DC-application” IEEE First International Conference on DC Microgrids (ICDCM). Atlanta. PP. 187-192. 07-10 June 2015

[11] Sungnim L. and Kim H. "A study on low-voltage DC circuit breaker” IEEE International Symposium on Industrial Electronics. Taipei, Taiwan. PP. 1-6. 28-31 May 2013

[12] Australian Government, Bureau of Meteorology http://www.bom.gov.au/climate/averages/tables/cw_066062.shtm l Accessed on 31-08-2015. 